of the local conditions which, if added to crowding, filth, or other insanitary conditions and want of proper ventilation, is that of all others which favours cholera. Such are the principal theories of the disease as they are supported by fact and argument which appear convincing. Europeans, Americans, and some authorities in India maintain the contagious view, whilst high authorities in India adhere to the opposite theory, and declare roundly that the facts of cholera, in India at least, are altogether opposed to the contagion theory.

On the question of importation of cholera in the Punjab epidemic (1875-6) and its spread by human agency, Dr. Bryden, in his report, p. 308 ( 1876 , published 1878 ), says : "The assertion amounts to this. The Punjab is divided into thirty-two districts. Cholera was introduced into seventeen of these in 1875 , and therefore it spread. Cholera was not introduced into fifteen districts, and therefore did not appear, or, if it was introduced, influences of which we know nothing stopped its propagation in these districts. Unknown causes prevailing in the one-half of the area are presumed to influence the human system so that it is capable of receiving cholera, and in the other to act universally as an antidote even to a cholera poison when introduced. This is what is oftered as antagonistic to the theory which asserts that cholera is air-borne and is as far-flying as are the limits of natural areas. Primarily, these theories cannot be reconciled; the one or the other is false. If cholera is spread only by the human being, the theory which shows it to be air-conveyed is untrue; if cholera is spread solely as an aërial miasm, then the theory which recognises only the effects of human intercourse is unfounded. The most that is admitted by the advocates of the human theory is, that the subjection of cholera to meteorological agencies is absolute, and that these influences can, and do operate so as to do away altogether with the effects of the poison, although imported. They do not recognise the entity minus the human being. The antagonistic theory, while holding, as opposed to demonstrable fact, the statement that cholera moves only by human agency, may, if necessary, be extended in its scope so as to embrace the other; that is to say, the inquiry is left open as to whether or not the cholera entity, after being aërially distributed, may be subsequently propagated or spread by man. In the theory which connects cholera solely with man there is no such extensibility. Human intercourse must explain every fact of spread and propagation, and nothing is left to the play of natural agencies. Human intercourse, giving the widest scope to the signification of the term, cannot pretend to account for any fundamental phenomenon displayed during the progress of epidemic cholera; and, therefore, I assert the theory to be radically untrue as applied to the behaviour of cholera in India. I do not say that the above statement will hold true all over the world ; and, even as applied to India, the theory does not preclude the possibility that cholera may be conveyed by the human being. Naturally the recoil is to the opposite extreme. The bold statement that cholera is never spread over an area unless human agency intervenes, is apt to be met by the equally dogmatic statement that cholera is as pure a miasm as malaria, and as little amenable to the control of man.

In the present state of our knowledge we can only be guided by the inferences from well-ascertained facts and such laws as we have ascertained to be in constant operation, watching and carefully observing until we may, were it only by a process of exclusion, arrive at some deeper knowledge still. "So far," says the chief sanitary authority in India, "the history of cholera is full of enigmas and seeming contradictions, and though we have of late years collected many valuable data, and understood the importance of studying them on a broad basis, we know no more of the exact cause of the disease than our grandfathers did. We know that, whatever the cause may be, it flourishes in the midst of insanitary conditions of dirt and overcrowding, and especially of impure water, impure from whatever cause; we know that it is liable to occur under certain conditions, and at certain times and seasons, and we should endeavour to extend that knowledge, and hope, as we do so, to arrive at the precise nature of the disease itself." But it may be well to remember that "expenditure of public money must take place only on observed facts and experience," not in accordance with theories. "It would be prejudicial to real sanitary work if opinions which have been promulgated in some parts of India, as to the cause of cholera being due solely to the state of the water-supply, were to take root."

It is most important that we should arrive at some definite conclusion as to the real nature of the disease, for it is impossible but that our conceptions on this subject must influence the sanitary measures that deal with it, and I believe the question must find its final solution in India, where the disease is always present in its endemic and seldom $=$ absent from the epidemic areas. The highest authorities-for both I have the greatest respect-differ toto calo on this subject. Is it that they are both right, though seemingly so opposed in their views? Like the knights who fought about the silver and golden sides of the shield, will they not change places, and find why they differed?

I would venture to suggest that in India the inquiry might be pushed with more detail in regard to individual cases and outbreaks in certain limited areas; and that, on the other hand, one or more epidemiologists of European fame should be deputed to visit India and study cholera with the eminent men who have devoted so many years of close attention to it there. It might be, I believe it would be, that mutually they would gain from each other, and that those who went out would tind their own views confirmed as to the disease in Europe-modified as to what they deemed it to be in India. Of one thing $I$ am convinced, that simple truth is the object of their search ; and I feel sure that from such combined action the greatest benefit would result.

\section{POPULAR NATURAL HISTORY}

TUDGING by the continuous stream of popular "Natural Histories," the demand for such books must be great. Messrs. Cassell have already published many volumes of the kind, some dealing with the whole animal kingdom, some with a single class; they are now bringing out a series of volumes under the editorship of Dr. Martin Duncan, and in the mean time they present us with a single volume of a still more popular character by Dr. Perceval Wright. This book, as we are told in the preface, is intended for that large class of readers who, while they take an intelligent interest in the study of natural history, have but little taste for the technical details which would naturally form the bulk of a scientific manual on the subject. For this reason the space devoted to the several orders is roughly proportioned to the amount of interest generally felt in them. The mammalia occupy more than a third of the volume, the remaining orders of the vertebrata about an equal space, while the whole of the invertebrates are compressed into the space that remains-about one-fourth of that occupied by the vertebrates. The author tells us that his aim has been "to compile a story-book about animals, and at the same time in some degree to write a scientific manual." This is undoubtedly a difficult thing to do, and to do it thoroughly and in the best style would be a fitting lifework for a great naturalist. It would have to be done as a labour of love, not to the order of a publisher; and the

1 Animal Life; being a Series of Descriptions of the Various Sub-kingdoms of the Animal Kingdom. By Perceval E. Wright, M.A., M.D , \&c., ProPetter, Galpin, and Co., London, Paris, and New York.) 
illustrations should be of the very best kind, so as fully to exhibit the beauty, the variety, and the intricacy of nature.

The present volume lays no claim to such completeness ; yet it is far superior to the mere popular natural history, inasmuch as it gives a considerable amount of accurate information both on the anatomy and physiology of the chief types of the animal kingdom, and on the geographical distribution of the chief families and genera of the higher animals. It also deserves great credit for the completeness of its review of the vertebrata, every well-established family group being referred to, and its more prominent characteristics usually described; so that, so far as this sub-kingdom is concerned, the book is a compendium of information well worthy of a place in the library of every natural history student. With the invertebrata a very different plan has had to be followed, only the more important orders being noticed, and a few typical forms selected for description and illustration; yet even here we are glad to meet with some account of the most recent discoveries among marine animals, and some illustrations which offer a welcome relief from the usual stereotyped forms of most popular works.

We shall best exbibit the character of Dr. Wright's volume by laying before our readers a few passages with their accompanying illustrations.

Under the mouse family (Muridæ) we have twenty species described or noticed, and these are illustrated by eight excellent figures. The beautiful illustration of the

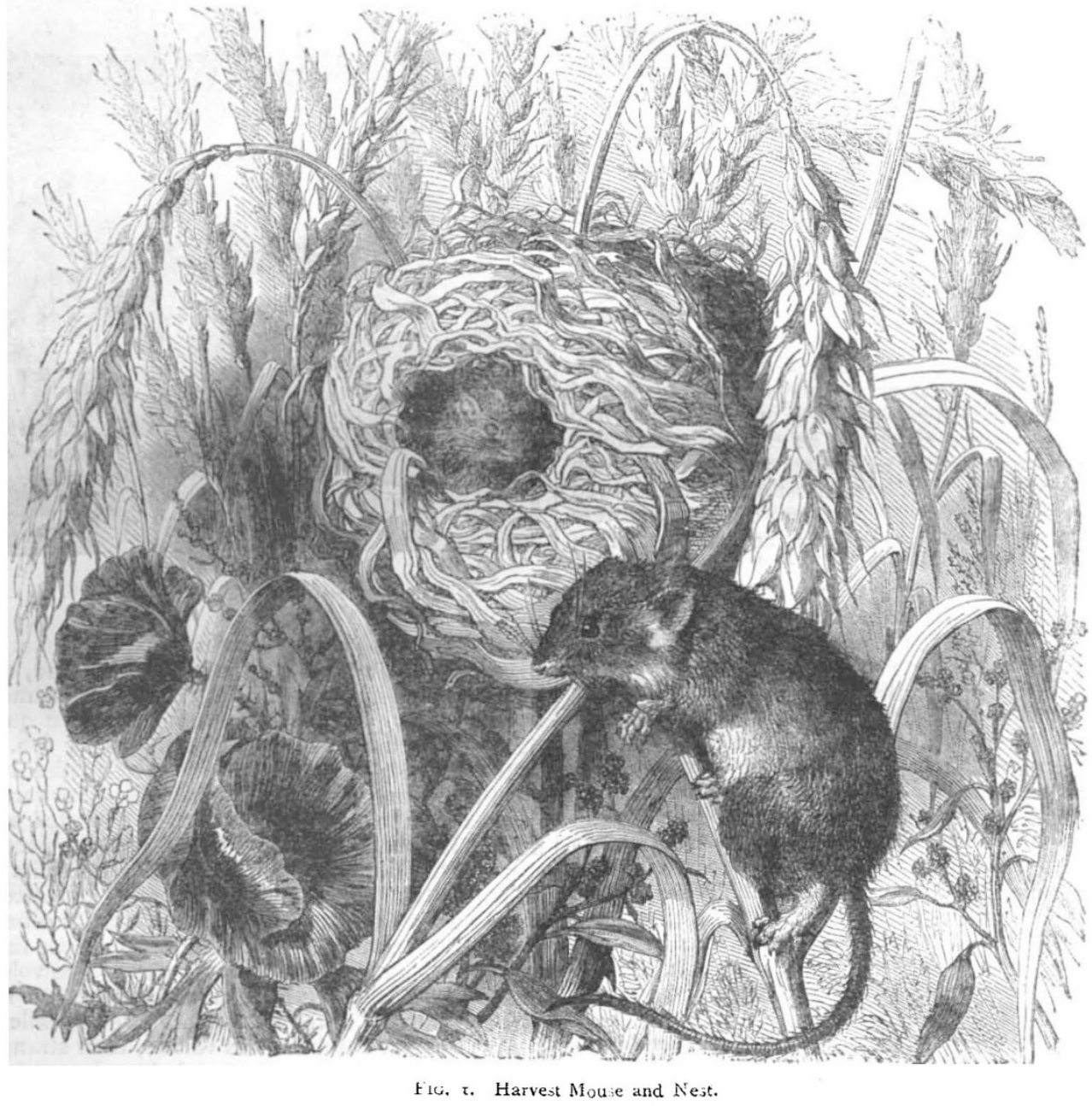

harvest-mouse nest building accompanies the following descriptive passage :-

"The Harvest Mouse (Mus minutus) is found probably all over Europe. It is not common in England, and is more frequent in Belgium. White, of Selborne, in writing to Pennant, says: 'They build their nests amidst the straws of the corn above the ground, and sometimes in thistles. They breed as many as eight at a litter, in a little round nest composed of the blades of grass or wheat. One of these I procured this autumn, most artificially platted, and composed of the blades of grass or wheat, perfectly round, and about the size of a cricketball, with the aperture so ingeniously closed that there was no discovering to what part it belonged. It was so compact and well-filled that it would roll across the table

without being discomposed, though it contained eight little mice that were naked and blind. As this nest was perfectly full, how could the dam come at her litter so as to administer respectively a teat to each ? Perhaps she opens different places for that purpose, adjusting them again when the business is over, but she could not possibly be contained herself in the ball with her young, which, moreover, would be daily increasing in bulk. This wonderful procreant cradle-an elegant instance of the efforts of instinct-was found in a wheat-field suspended in the head of a thistle.' The food of this little mouse consists of corn and grass seeds, insects, and earth-worms. Of insects it is very fond."

Of the ravages of another British species we have the following interesting account :- 
"The Short-tailed Field Mouse (Arvicola arvalis) is found throughout Europe to Siberia. Small and insignificant as this animal appears to be, there is scarcely a species among the rodents more destructive to our fields, gardens, and woods. In the corn-field, the rick-yard, the granary, and in extensive plantations, its depredations are often severe, and even calamitous. Of the damage effected by a multitude of these animals we give a single instance. In the year I8I4 the whole, both of Dean and New Forest, appeared to be largely stocked with mice ; at least wherever the large furze-brakes in the open parts had been burnt their holes and runs covered the surface. Hayward Hill, a new plantation of about 500 acres in the Forest of Dean, was particularly infested. This inclosure, after being properly fenced, was planted with acorns in 1810 , and in the following spring about one-third came up, the rest of the seed having been destroyed principally by mice. The young shoots of the natural hollies of the district, which had been cut down to favour the plantation, were not attacked by the mice in the following winter, though their runs were numerous. In the autumn of the succeeding year a large quantity of five years old oaks and chestnuts, with ash, larch, and fir, were planted in the inclosure. In the winter the destruction began, and numbers of the hollies, then two, three, or more feet in height, were barke, round from the ground to four or five inches upwards, and died. In the succeeding spring a number of the oaks and chestnuts were found dead; and when they were pulled up it appeared that the roots had been gnawed through two or three inches below the surface of the ground; many were also barked round and killed, like the holly-shoots, whilst others, which had been begun upon, were sickly. The evil now extended to the other inclosures, and becoming very serious both in Dean Forest and the New Forest, cats were turned out, the bushes, ferns, rough grass, and other plants were cleared off to expose the mice to beasts and birds of prey; poisons in great variety were laid, and seven or eight different sorts of traps were set for them, some of which succeeded very well. These were, however, superseded by the plan of a ratcatcher, who, having been employed to capture the mice, had observed, on going to work in the morning, that some of them had fallen into wells or pits accidentaily formed, and cuuld not get out again, many of them dying from hunger or fatigue in endeavouring to climb up the sides. Such pits were therefore tried on his recomm endation. They were at first made three feet deep, three long, and two wide ; but these were found to be unnecessarily large, and after various experiments it appeared that they answered best when from eighteen to twenty inches deep, about two feet in length, and a foot and a half in width at the bottom, and only eighteen inches long and nine wide at the top, or so wide as would allow of the earth being got out of a hole of that depth, for the wider they were below and the narrower above the better they answered their purpose. ${ }^{1}$ They were made about twenty yards asunder, or, where the mice were less numerous, thirty yards apart. Nearly 30,000 mice were speedily caught by this method in Dean Forest, and in the New Forest about 10,000 more. It was believed that a far greater number had been taken out of the holes either alive or dead by stoats and weasels, or by kites, owls, crows, jays, and magpies."

The following account of the Angler (Lophius piscatorius), a curious large-headed fish belonging to the family of the Lophiidæ, or fishing-frogs, and a native of our seas, is short, but clear and instructive :-"This curious fish has the head wide, and the mouth nearly as wide as the head; the eyes are large; the lower jaw, which is the longer, is bearded or fringed all round the edge, and both jaws are armed with numerous teeth; the body is narrow compared with the breadth of the

\footnotetext{
2u This is the form adopted for the tiger-pits made by the Chinese in Singap $>$ re.
}

head, and tapers gradually to the tail. The colour of the upper surface of the body is uniform brown, the under surface white, and the tail almost black. On the top of the head are three long filaments; of these, two are seated just above the muzzle, the other rises from the back of the head. These filaments are movable in all directions, especially the first, which, tapering like the finest fishing-rod, ends in broad, flattened, silvery tips.

"The angler is insatiably voracious, but it is a slow swimmer; it is formed, in fact, for taking its prey in ambush. It reposes on the soft mud or sand, in some favourable lurking-place, and, stirring up the mud with

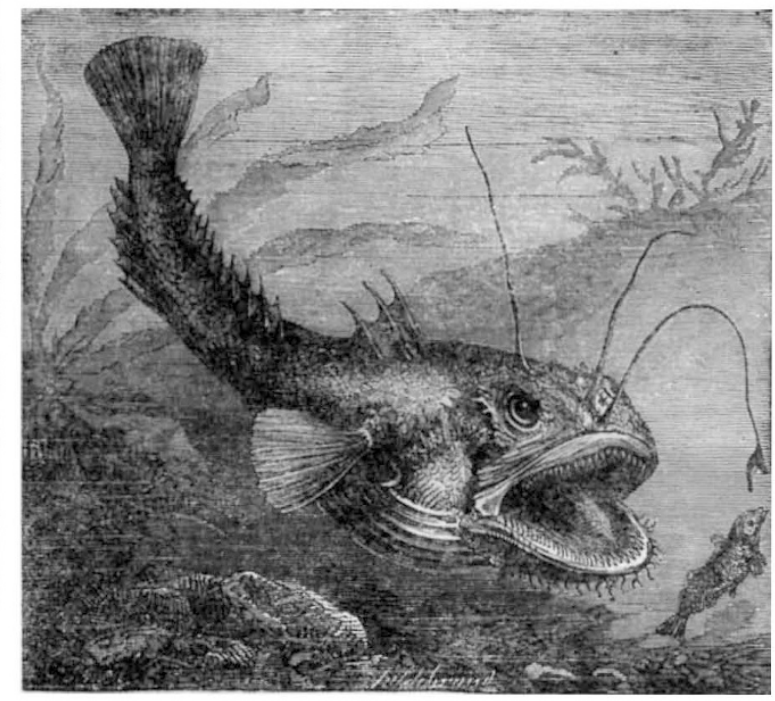

Fig. 2.-Angler (Lophuzs piscatorius).

its pectoral fins, thus obscures itself in a murky cloud, beyond which appear its long filaments, and, especially the first, with its glittering tip, offering an attractive bait to other fish. Thus stationed, the creature quietly expects its victim. On rove the shoals of fish, eager in quest of food. They pass one after another in succession, till at length one espies the bait. Forward the fish darts, either to examine or seize the expected prize; but at that instant, aided by its broad, feet-like pectoral fins, the watchful angler springs up and captures its prey."

The fishes are generally very well illustrated, and a large number of interesting species are described.

Passing on to the invertebrates, we come first to the insects, which form the weakest part of the volume; but this is perhaps of less importance as none but specialists feel any interest in the bulk of the forms; while their immense numbers and endless variety, their strange habits, and marvellous instincts can only be adequately set forth where ample space can be afforded them. We pass on therefore to the lower marine animals, and select as an example of the way they are treated a rare British species allied to the sea cucumbers, and named Synapta duvernea. It was discovered in the English Channel by M. Quatrefages, who thus describes it:-

"Imagine a cylinder of rose-coloured crystal as much as eighteen inches long and more than an inch in diameter, traversed in all its length by five narrow ribbands of white silk, and its head surmounted by a living flower whose twelve tentacles of purest white fall behind in a graceful curve. In the centre of these tissues, which rival in their delicacy the most refined products of the loom, imagine an intestine of the thinnest gauze, gorged from one ento the other with coarse grains of granite, the rugged points and sharp edges of which are perfectly perceptible 
to the naked eye. But what most struck me at first in which enabled the Synapta to crawl up the side of a this animal was that it seemed literally to have no other nourishment than the coarse sand by which it was surrounded. And then when, armed with scalpel and microscope, I ascertained something of its organisation, what unheard-of marvels were revealed! In this body, the walls of which scarcely reach the sixteenth part of an inch in thickness, I could distinguish seven distinct layers of tissue, with a skin, muscles, and membranes. Upon the petaloid tentacles I could trace terminal suckers, phenomenon will be observed. The animal, being unable

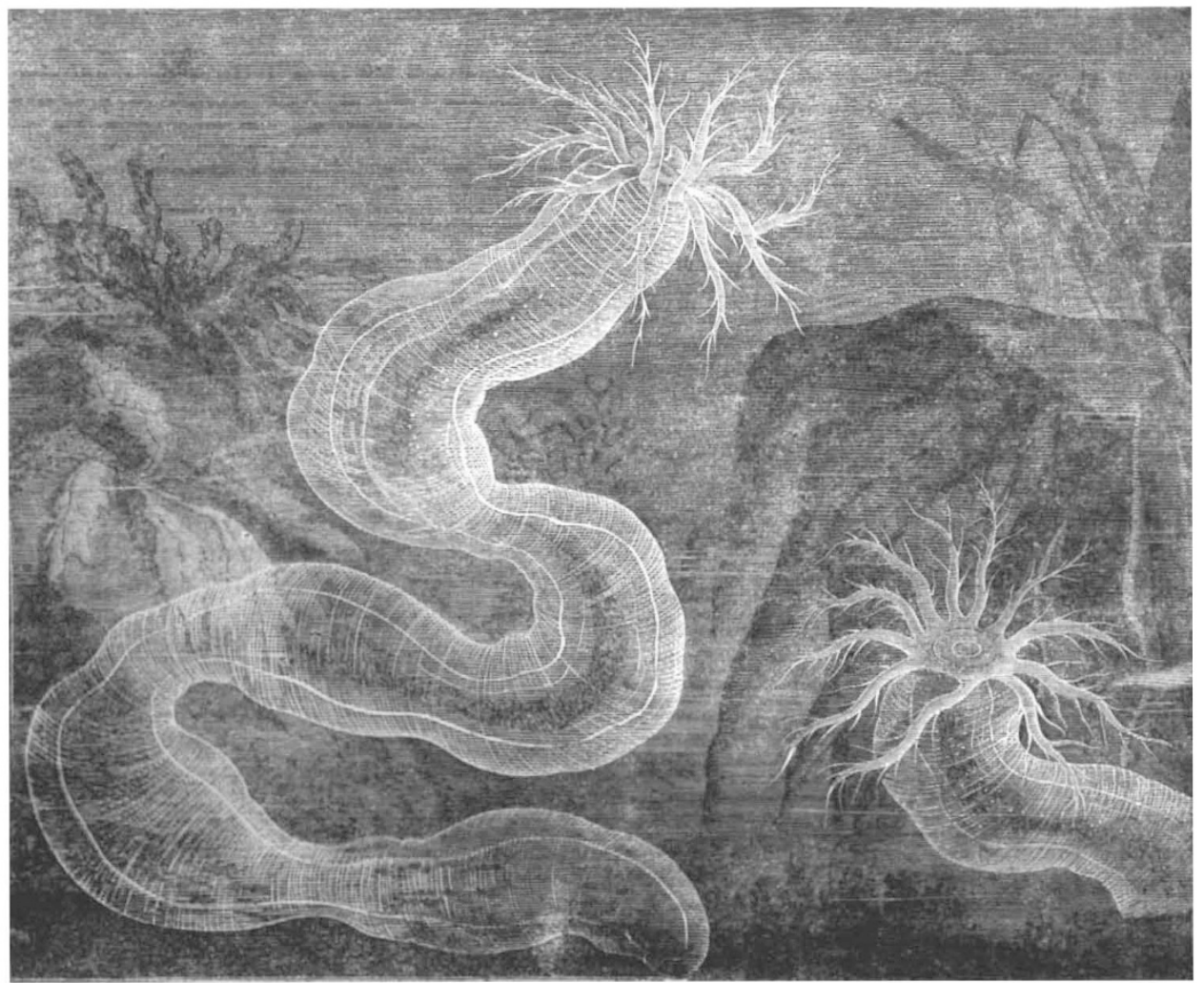

F1G. 3.-Synapta duvernea.

to feed itself, successively detaches various farts of its own body, which it amputates spontaneously."

Although most of the illustrations in this volume are very good, and some are good works of art, there are also several which are very poor, and quite unworthy of the text. This is especially the case among the smaller birds, several of which are unrecognisable. A few also have been wrongly named, representing very different creatures from those they are said to be. The most prominent defects of this kind are the figure of the Leucoryx antelope, which is named Saiga tartarioa, and highly-polished vase. In short this creature, denuded to all appearance of every means of attack or defence, showed itself to be protected by a species of mosaic, formed of small, calcareous, shield-like defences, bristling with double hooks, the points of which, dentated like the arrows of the Carribeans, had taken hold of my hands. If one of these Synapta is preserved alive in sea-water for 